\title{
Prediction of Prospective Mathematics Teachers' Academic Success in Entering Graduate Education by Using Back-propagation Neural Network
}

\author{
Elif Bahadır \\ Correspondence: Elif Bahadır, Department of Primary Mathematics Education, Faculty of Education, Yıldız Technical \\ University, Istanbul, 34210, Turkey
}

Received: January 21, 2016

doi:10.11114/jets.v4i5.1321
Accepted: February 22, $2016 \quad$ Online Published: March 14, 2016

URL: http://dx.doi.org/10.11114/jets.v4i5.1321

\begin{abstract}
The purpose of this study is to examine a neural network based approach to predict achievement in graduate education for Elementary Mathematics prospective teachers. With the help of this study, it can be possible to make an effective prediction regarding the students' achievement in graduate education with Artificial Neural Networks (ANN). Two different neural networks are used for an effective prediction of the first network in which some core courses are taken by prospective Mathematics teachers in their first two years, including General Mathematics, Pure Mathematics, Analysis I, Analysis II, Geometry, Linear Algebra-I. The scores received from the above courses are used as an input for the back-propagation neural network (BPNN). Additionally, the scores of vocational core courses taken by third year students, including Analysis3, Special Teaching Methods 2, Elementary Number Theory, Algebra, Problem Solving, are used as the output of the BPNN. The second network uses the scores of all courses which are previously mentioned and uses them as an input of BPNN and also uses ALES (Academic Personnel and Postgraduate Education Entrance Exam) score. They are used as an output of the BPNN. Besides, the correlation analysis is conducted by using the average graduation and ALES scores components. Analytical results demonstrate that the BPNN model offers relatively accurate predictions for the student success in graduate education with a high average of accuracy (Neural Network1 is $77.125 \%$ and Neural Network2 is $68.5 \%$ ). Another finding is that there is no significant correlation between the graduate average scores of candidates who qualified for a graduate education and their ALES scores. These results indicate that BPNN is a suitable tool to predict the academic success of all education majors. Student career advisors can use the ANN model to identify the students who have particular potential for graduate education, and this prediction model can help these students adjust their own teaching strategies, and provide guidance and support for their careers.
\end{abstract}

Keywords: artificial neural network, back-propagation neural network, mathematics teacher education, post-graduation education, predict

\section{Introduction}

Predicting students' academic performance is critical for educational institutions, because it allows them to develop strategic programs that will help to improve students' performances during their period of study in an institution. Graduate education is becoming increasingly important in the academic teaching industry, as well as, in other sectors. Higher education access has an increasing potential because of individual, institutional, social, economic and some other factors (Tural 2004; Ekinci 2009) especially in the last 20-25 years, the increasing dissemination and participation in higher education has become one of the increasing political purposes of the country (Ekinci 2011).

In the new millennium, one of the core issues in educational reform is the development of a highly qualified teaching force that will be prepared to meet the demands of the paradigm shifts in school education (Fullan 1998). In such an era of fast transformations, teachers, as key agents in school education are expected to face new expectations, challenges and uncertainties in the discharge of their professional duties of preparing their young people for success in the new century (McGhan 2002; Wheatley 2002). International research has identified clearly the impact of teachers on the learning of young people (Hattie 2002). The question is often raised about how adequately teacher education has empowered teachers to take up the new roles and perform teaching effectively.

Teacher education provided by education faculties in Turkey is carried out by similar institutions in different countries; Arslan \& Ozpinar (2008), after viewing recommended source books and interviewing with prospective teachers, stated that future Turkish teachers have been educated to have essential fundamental skills and knowledge. Although 
prospective teachers are given sufficient pre-service education, certain studies show that teachers who are currently serving have difficulties in many different issues. For example; applying new primary school curriculum (Dindar \& Yangin, 2007); integrating ICT in instruction (Goktas, Yildirim \& Yildirim, 2008; Usluel, Mumcu \& Demiraslan, 2007; Umay, 2004); reflective teaching skills (Duban \& Kucukyilmaz, 2008); assessment (Orbeyi \& Guven, 2008, Duban \& Kucukyilmaz, 2008); teaching and learning processes (Kincal, Ergul \& Timur, 2007).

All the above show that teachers still have certain weaknesses after the pre-service education they received. On the other hand, even experienced teachers face unexpected, extreme situations and problems that need to be overcome. At the same time, in this age of fast technological and social advancements, student needs are diversifying continuously along with the fast propagating knowledge (Alan and Kara, 2010).

In this case, graduate education is becoming more important. Graduate education provides teachers opportunities of gaining new knowledge and skills by influencing student learning through practicing these knowledge and skills and contributing school development by affecting other teachers. Teachers are supposed to have these knowledge and skills at the end of faculty (Day, 1999). The basic skills of mathematics teachers which are related with their personalities and professions, teaching-learning process and assessment are acquired or improved in graduate education (Alan and Kara; 2010).

Prospective Mathematics teachers prefer graduate education, because they want to teach effectively, continue their academic careers or find a more qualified job in private schools. The approval for graduate education is limited, but students' demands are increasing. Since there are limited chances for being a public teacher, prospective teachers try to have a graduate education to become more qualified for other choices.

Not all the students enter the graduate programs in Turkey because of the undergraduate and graduate education policy. ALES (Academic Personnel and Postgraduate Education Entrance Exam) score and the average graduation score are most important components to qualify for graduate education in Turkey. ALES is an exam used to indicate the level of basic logic and reasoning skills. Therefore, majority of prospective mathematics teachers can get high scores from this examination.

When we analyze the studies focusing teachers' graduate education, it is seen that they have been clustered around certain issues: problems faced by teachers having graduate degrees and suggestions to solve them (Kuzu \& Becit, 2007; Guven \& Tunç, 2007; Aslan, 2007; Bakioğlu \& Gürdal, 2001), expectations of graduate students and actualization level of these expectations (Demir, 2007) efficiency of the graduate education obtained (Bumen, 2006). In an exceptional study, Alhas (2006), with a questionnaire, tried to determine the opinions of teachers having graduate degrees about skills they acquired and functions of graduate education.

The purpose of this research is to be able to make an effective prediction regarding the students' success in graduate education with Artificial Neural Networks (ANN) which is used as an effective prediction method in various sectors, as an alternative to traditional methods in the field of education. It was observed that there have been no studies, at least in Turkey, in order to make an effective prediction regarding the students' success in graduate education with Artificial Neural Networks (ANN).

Many of the prior studies involving graduate student performance have used linear regression models to estimate student academic performance based on their pre-admission record of achievements. Gayle and Jones (1973) and Baird (1975) found a significant positive relationship between Graduate Records Examination (GRE) scores and graduate grade point average (GPA) in graduate students. Studies by Lee (2010) used a neural network based approach for predicting the learning effect in design students with an average accuracy of $93.54 \%$. Studies by Jun (2005) and Herrera (2006) provide a comprehensive overview of the theoretical models describing student persistence and dropout in both contact and distance education institutions. Deckro and Woundenberg (1972) studied nine variables as possible predictors of academic success among Kent State MBA students.

Paolillo (1982) employed step-wise regression in his study and found that the applicant's junior and senior undergraduate grade point average was the first variable to enter into the equation. Schwan (1988) found GPA to be significantly correlated with GMAT score, undergraduate grade point average, and junior/senior grade point average among Murray State University MBA students. This research is to be able to make an effective prediction regarding the students' success in graduate education with Artificial Neural Networks (ANN). Two different neural networks are used to effectively estimate the first network takes the grades of all courses taken by first-year Mathematics teacher candidates, including General Mathematics, Pure Mathematics, Analysis I, Analysis II, Geometry, Linear Algebra-I, and uses these grades as the input of the back-propagation neural network (BPNN). Additionally, the grades of professional core courses at the upperclassman level, including Analysis3, Special Teaching Methods 2, Elementary Number Theory, Algebra, Problem Solving, are used as the output of the BPNN. The second network takes the grades of all courses taken by all courses mentioned above and uses these grades as the input of BPNN and the grades of ALES (Academic 
Personnel and Postgraduate Education Entrance Exam) score, is used as the output of the BPNN. Additionally, the correlation analysis which was made with the average graduation and ALES score components.

"A Neural Network is basically a simplified model of the way the human brain processes information. It works by simulating a large number of interconnected simple processing units that resemble abstract versions of neurons. The processing units are arranged in layers. There are typically three parts in a neural network: an input layer, with units representing the input fields; one or more hidden layers; and an output layer, with a unit or units representing the output field(s). The units are connected with varying connection strengths (or weights). Input data are presented to the first layer, and values are propagated from one neuron to the other neuron on the next layer. Eventually, a result is delivered from the output layer. The network learns by examining individual records, generating a prediction for each record, and making adjustments to the weights whenever it makes an incorrect prediction. This process is repeated many times, and the network continues to improve its predictions until one or more of the stopping criteria have been met. Initially, all weights are random, and the answers that come out of the net are probably nonsensical. The network learns through training. Examples for which the output is known are repeatedly presented to the network, and the answers it gives are compared to the known outcomes. Information from this comparison is passed back through the network, gradually changing the weights. As training progresses, the network becomes increasingly accurate in replicating the known outcomes. Once trained, the network can be applied to future cases where the outcome is unknown" (SPSS, 2006).

"Several types of neural networks exist. Among them, the feed-forward neural networks are the most popular architectures due to their structural flexibility, good representational capabilities, and availability of a large number of training algorithms (Haykin, 1999). This Network comprises neurons arranged in layers in which every neuron is connected to all neurons of the next layer (a fully connected network). Multilayer perception neural networks (MLPs) are a type of feed-forward network consisting of an input layer of nodes followed by two or more layers of neurons with the last layer being the output layer. The input layer is first layer and it accepts symptoms, signs, and experimental data. The layers between the input and output layers are referred to as hidden layers. Outputs of neurons in one layer are inputs for the next layer. There are no connections between non-adjacent layers and no connections between neurons in the same layer. Connections between layers go in only one direction, i.e. there are no feedbacks. The back-propagation algorithm is most widely used to adjust the network parameters which were established by Rumelhart, Hinton, and Williams (1986). According to this algorithm, information is passed forward from the input nodes through the hidden layers to the output nodes and the error between the desired response and the actual response of the network is computed. This error signal is then propagated backwards to the input neurons adjusting the network weights and biases.

This process is repeated for each sample in the training set. As soon as the entire training set has been presented to the network, an epoch has elapsed. The training phase may comprise several epochs (Lykourentzou, Giannoukos, Mpardis, Nikolopoulos, \& Loumos, 2009). A popular approach to optimizing the performance of back-propagation is the Levenberg-Marquardt algorithm (Marquardt, 1963) which has been exposed to increase the speed of convergence and effectiveness of the moderate-sized network training (Hagan, Demuth, \& Beale, 1996; Hagan \& Menhaj, 1994). During the training phase, a network may end up memorizing the training data and thus lose its ability to generalize from the training samples to an unseen population. This phenomenon is called over-fitting and can be avoided by employing a separate data set called the validation set. The network parameters are estimated based only on the training set and the performance of the network is assessed by computing the MSE on the validation set. When the network performance deteriorates, it usually means that over-fitting has occurred. Training then stops and the parameters of the best previously trained network are stored. The training phase can be terminated by reaching a minimum in the cost function, by meeting the performance goal, or by detecting that the validation set produced increasing MSE. Finally, after the training is finished, the network test phase occurs. During this phase, unseen data are presented to the trained network to appraise its performance. These data comprise the test set that is disjoint to both the training and the validation data sets" (Kardan et al, 2013:4).

\section{Method}

This study aims to analyze the usage of the BPNN model as a decision-making tool to predict learning effect for students of Elementary Mathematics Teaching students. During the process of making predictions regarding the academic achievements of prospective teachers; students' scores from specified courses during graduate education and ALES scores were taken into consideration and it was tried to predict the achievements of students by using all these data as predictive variables. Additionally, the correlation analysis was made between academic graduation average point (GPA) and ALES scores components.

\subsection{Collecting Data}

The study collected the grade information of students who graduated from the Department of Mathematics Education. 
The information comprised not only the first-year grades of the students in all courses, including General Mathematics, Pure Mathematics, Analysis I, Analysis II, Geometry, Linear Algebra-I, but also the professional core course grades at the next grade level, including Analysis3, Special Teaching Methods 2, Elementary Number Theory, Algebra, Problem Solving.

Grade information was recorded for 220 students in total. Afterwards, this information was employed for the training and testing stages of the BPNN. In order to assess the ability of the BPNN model to predict learning effect in students of Elementary School Mathematics teaching, 176 data sets $(80 \%$ of the total grades information) were randomly selected from the 220 data sets of the total grade information used for BPNN model building; i.e. the training samples. The remaining 44 data sets ( $20 \%$ of the total grades information) then were used to test the prediction accuracy of the BPNN model; i.e. the testing samples.

Table 1. The Data Set of the Implementation

\begin{tabular}{|c|c|c|c|c|c|}
\hline $\begin{array}{l}\text { Data } \\
\text { No }\end{array}$ & Set & $\begin{array}{l}3 \text { Different Universities Educational Sciences, } \\
\text { Teaching Elementary School Mathematics }\end{array}$ & Input Years & Number of Data & Total \\
\hline \multirow{8}{*}{\multicolumn{2}{|c|}{1}} & who are getting/got a master's degree between & 2006 & 4 & \multirow{8}{*}{80} \\
\hline & & 2006-2010 (only Marmara University) & 2007 & 6 & \\
\hline & & & 2008 & 5 & \\
\hline & & & 2009 & 11 & \\
\hline & & & 2010 & 13 & \\
\hline & & & 2011 & 15 & \\
\hline & & & 2012 & 14 & \\
\hline & & & 2013 & 12 & \\
\hline \multirow{3}{*}{\multicolumn{2}{|c|}{2}} & who graduated from graduate education in years & 2008- 2011 & 140 & \multirow{3}{*}{140} \\
\hline & & $2010-2011$ & & & \\
\hline & & (3 Different Universities) & & & \\
\hline 3 & & $\begin{array}{l}\text { who entered a faculty in } 2010 \text { and continue his/her } \\
\text { graduate education (3 Different Universities) }\end{array}$ & $2010-2014$ & 152 & 152 \\
\hline
\end{tabular}

Data were collected from 3 different universities (Marmara University, Yıldız Technical University, Necmettin Erbakan University). The data used in this study were taken from Marmara and Necmettin Erbakan Universities for the training of the network because Yildız Technical University graduate education program is not ready yet.

In the data set, the data are separated randomly into two sections as training and test sets. Training set is mainly used to learn which is suitable to the significance of the data. Test set is completely used for evaluating the performance of a specific classifier. The training set is used for the training of the networks and the test set is used for assessing the performance of training in the implementation. $80 \%$ of the data set is composed of training set and $20 \%$ of it is composed of test set. Besides, before this analysis, the number of neurons at the secret layer is determined by looking at the significance of a classifier which is called as validity set.

In order to evaluate the number of secret layers in a problem, the performance of the validity data is analyzed. In order to test the performance of the network structure, Mean Square Error (MSE) and Mean Absolute Error are employed.

For the network, 1000 iterations were carried out. As a result of the neural network analysis, separate classification tables were obtained for each set. The accuracy percentages obtained from each set are different. While calculating the general accuracy percentage, the results obtained from three sets should be combined.

The accurate classification percentage of the training set was found for each event. Absolute error mean and mean square error were found. Training set classification table was created for implementation that will be predicted and the accurate classification percentage was found for test set. In order to obtain classification table according to ANN implementation, training, validity and test sets were combined. The assigning values are added while combination is being carried out. The obtained data were given in tables at the end of the section regarding implementation.

\section{Method of Analysis and Results}

Two different network structures were used for the study. ALES score and graduation point are two important requirements to be admitted for graduate education. BPNN was employed in order to recognize the links between graduate score and ALES score for predicting prospective teachers' entering graduate education. In addition, the correlation analysis was made between academic graduation average point (GPA) and ALES scores components. 


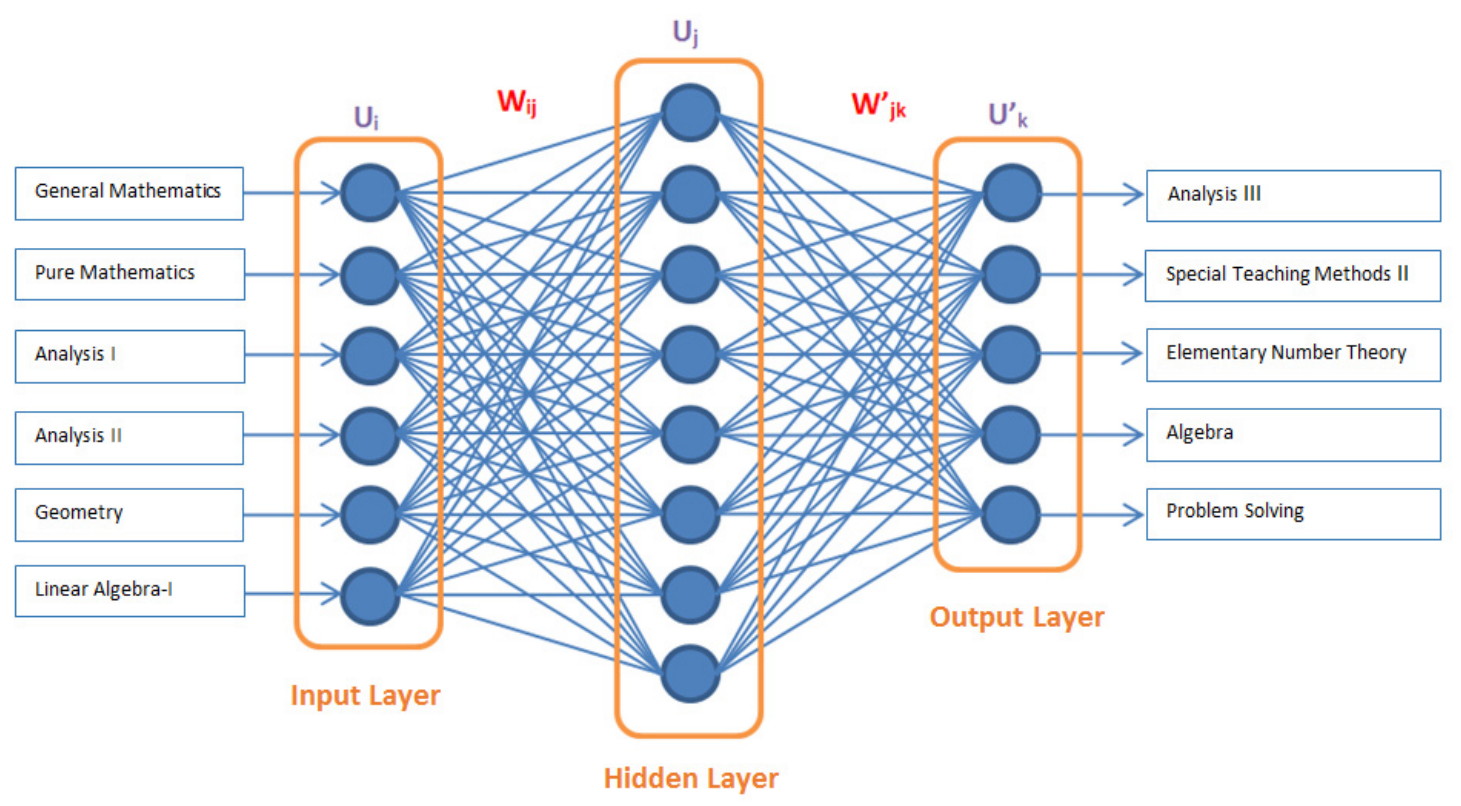

Figure 1. Architecture of three-layer BPNN in this study (Neural network 1: 6 Input, 5 Output Layered Network Model.)

The network1 shown in Figure 1 is a feed-forward neural network which consists of three layers. The input layer has a total of 6 nodes. Each node represents first-year courses of a graduate education. The output layer has 5 nodes which represent the upperclassman courses a graduate education. The network2 shown in Figure 2 is a feed-forward neural network which consists of three layers. The input layer has a total of 11 nodes. Each node represents a graduate courses. The output layer has one node which represents the ALES score.

Input layer:

The input layer, including General Mathematics, Pure Mathematics, Analysis I, Analysis II, Geometry, Linear Algebra-I, are taken as input variables (i.e. input nodes) in the input layer of the BPNN. Therefore, the input layer contains a total of six nodes.

\section{Output layer:}

The output layer, including Analysis III, Special Teaching Methods 2, Elementary Number Theory, Algebra, and Problem Solving are used as the output variables (i.e. output nodes). The output layer contains these five nodes.

The academic achievement prediction was made with the field courses taken at the first years of the faculty for the analyses carried out by moving from the grade data of the 292 students. The network pattern of BPNN which has 6 inputs and 5 output layers used in the study can be seen in figure 1 . The information which is given after the figure is as in the following; the input and output layers in ANN, the number of examples and the transfer function of the BPNN model together with the number of operation elements at secret layer, learning theorem and threshold level which was identified for obtaining the expected error value. Mean square error (MSE) value kept learning until it reached the threshold level. While doing this, it employed the minimum function. When the expected error value was reached, the number of learning was stopped before reaching 10000 .

58 of 292 data were used to test data. The data in the training set and the network were trained and the possibility of generalizing the results produced by the network was tested. For the test data, 29 data in our data table were selected as Successful ' 1', and the other 29 data were selected as Unsuccessful ' 0 '. The total number of the test data was 58 . The training of network lasted during 10000 iteration and then it was over. However, if the set of MSE for the verification set had increased, the training would have been stopped at that point before 10000 iteration. The regulation of significances was carried out after all the samples in the training set had been shown to network.

Input layer for figure 2:

The input layer, including General Mathematics, Pure Mathematics, Analysis I, Analysis II, Geometry, Linear Algebra-I, Analysis III, Special Teaching Methods 2, Elementary Number Theory, Algebra, Problem Solving are taken as input variables (i.e. input nodes) in the input layer of the BPNN. Therefore, the input layer contains a total of eleven nodes. 
Output layer for figure 2:

The output layer, including ALES score is used as the output variables (i.e. output nodes). The output layer contains one node. The academic achievement prediction was made with the field courses taken at the first years of the faculty for the analyses carried out by moving from the grade data of the 140 students. The network pattern of BPNN which had 11 inputs and 1 output layers used in the study can be seen in figure 2 . The information which is given after the figure are as in the following; the input and output layers in ANN, the number of examples and the transfer function of the BPNN model doing this, it employs the minimum function. When the expected error value was reached, the number of learning was stopped before reaching 10000 .

28 of 292 data were used as the test data. The data in the training set and the network were trained and the possibility of generalizing the results produced by the network was tested. For the test data, 14 data in our data table were selected as Successful ' 1 ', and the other 14 data were selected as Unsuccessful ' 0 '.together with the number of operation elements at secret layer, learning theorem and threshold level which was identified for obtaining the expected error value. Mean square error (MSE) value keeps learning until it reaches the threshold level.

The total number of the test data was 58. The training of network lasted during 10000 iteration and then it was over. However, if the set of MSE for the verification set had increased, the training would have been stopped at that point before 10000 iteration. The regulation of significances was carried out after all the samples in the training set were shown to network.

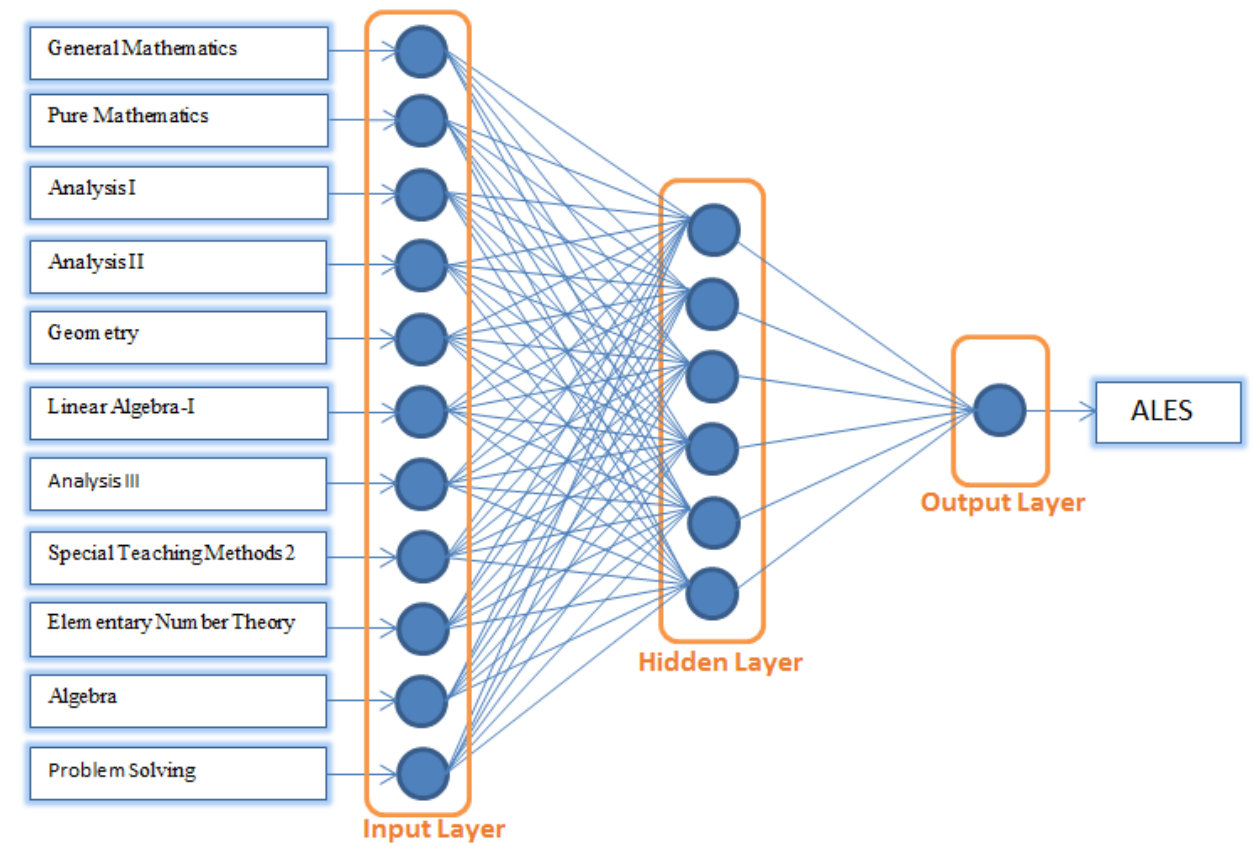

Figure 2. Architecture of three-layer BPNN in this study (Neural network 2: 11 Input, 1 Output Layered Network Model.)

\subsection{Experimental Results}

\section{Results of ANN 1}

In our case, a back-propagation network with three layers seemed to be the most appropriate. The input layer had 6 neurons and the output layer had 5 neurons and the number of nodes in the hidden layer was 8 . The prediction equation predicted classification group membership correctly with an average of $77.125 \%$

\section{Results of ANN 2}

In our case, a back-propagation network with three layers seemed to be the most appropriate. The input layer had 11 neurons and the output layer had 1neuron and the number of nodes in the hidden layer was 6 . The prediction equation predicted classification group membership correctly with an average of $68.5 \%$ 
Table 2. Performance when tested with testing data.

\begin{tabular}{lll}
\hline Performance & Successful & Unsuccessful \\
\hline MSE & 0.22 & 0.21 \\
NMSE & 2.18 & 2.15 \\
MAE & 0.36 & 0.35 \\
Min Abs Error & 0.00 & 0.00 \\
r & 0.21 & 0.21 \\
Percent Correct & 71.18 & 65.82 \\
\hline
\end{tabular}

After optimizing the network's structure and training the data within 1000 epochs, we tested the network's predictive power on the data set. The network successfully classified the data as $68.5 \%$

\section{Results of correlation analysis}

The correlation analysis was made between the average graduation point (GPA) and ALES score components.

Table 3. The correlation between the average graduation and ALES score

\begin{tabular}{|c|c|c|c|}
\hline & & $\begin{array}{ll}\begin{array}{l}\text { The } \\
\text { graduation }\end{array} & \text { average } \\
\end{array}$ & ALES score \\
\hline average & Pearson Correlation & 1 & .422 \\
\hline \multirow[t]{2}{*}{ graduation } & Sig. (2-tailed) & & .256 \\
\hline & $\mathrm{N}$ & 80 & 80 \\
\hline \multirow{3}{*}{ ALES score } & Pearson Correlation & .422 & 1 \\
\hline & Sig. (2-tailed) & .256 & \\
\hline & $\mathrm{N}$ & 80 & 80 \\
\hline
\end{tabular}

According to the correlation results; the correlation between the average graduation and ALES score seemed to have had no significant correlation between the two data $(\mathrm{r}=0.422, \mathrm{p}>.05)$. This analysis was carried out with the students who received/were receiving graduate education between the years of $2006-2013$.

Table 4. Prediction results from two different Neural Networks

\begin{tabular}{cccc}
\hline Methods & Overall Accuracy & $\begin{array}{c}\text { Sum of Mean Square Error } \\
\text { (MSE) }\end{array}$ & $\begin{array}{c}\text { Mean Absolute Error } \\
\text { (MAE) }\end{array}$ \\
\hline Neural Network1 & 77.125 & 0.18 & 0.30 \\
Neural Network2 & 68.5 & 0.21 & 0.35 \\
\hline
\end{tabular}

Recognizing that prediction constitutes an excellent first toward intervention and considering the classification power of ANN's turned into ANN technology to predict successful academic achievement rates.

\section{Discussion}

The research tested which model should be used to predict success the artificial neural networks model to what extent succeeded and focused on determining which predictions made with the help of these models had successful outcomes. It also showed the value of the ANN. It is possible to determine and guide prospective teachers who are planning to have graduate education in accordance with the successful forecasts of prediction methods.

The identification of the contributory parameters can be conducted by performing sensitivity analysis. Saltelli at. all. (2004), Karamouzis \& Vrettos (2008) have reached similar conclusions in their studies. Although the difference in error values produced by prediction models mentioned in studies was not high, the fact that neural network model was more successful than all the other data sets showed us that artificial neural network technique could be an alternative technique for classical statistic methods in educational studies depending on prediction. The findings are quite consistent with other published research results. For example, Lee (2010), Naik\& Rogotman (2009), Ibrahim \& Rusli (2007), Schwan (1988), Amanatiadis, Mitsinis, \& Maditinos (2014)

According to the correlation results; the correlation between the average graduation and ALES score seemed to have had no significant correlation between the two data $(\mathrm{r}=0.422, \mathrm{p}>.05)$. This analysis was carried out with the students who received/were receiving graduate education between the years of $2006-2013$.

ALES is an exam based on logic and reasoning skills, so majority of prospective mathematics teachers receive high marks from this examination. That there was no significant relationship between GPA and ALES scores can be explained by high scores of the mathematics teaching students. These results indicate that BPNN is a suitable tool for predicting success of the students who are studying in education majors. Student career advisors can use the ANN model to identify the students who have particular potential for graduate education, and this prediction model can help these students adjust their own teaching strategies, and provide guidance and support for their careers.

Following studies should identify the student parameters that can be contributory to successful predictability rates. For example; students' genders, family incomes, foreign language knowledge, etc. can be taken into consideration in the future studies. 


\section{References}

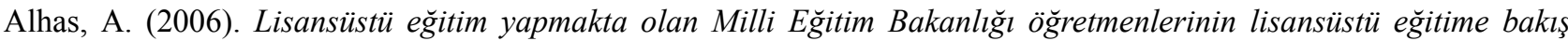
açıları. "Graduate graduate education perspectives of the Ministry of Education to make education teacher”.Master's Dissertation, Institute of Educational Sciences, Gazi University, Ankara. http://tez2.yok.gov.tr/

Amanatiadis, A., Mitsinis, N., \& Maditinos, D. (2014). A Neural Network-Based Approach For User Experience Assessment, Behaviour \& Information Technology. http://dx.doi.org/10.1080/0144929X.2014.921728

Arslan, S., \& Kara, F. (2010). The Postgraduate Education of Teachers and its Effects on Their Instructional Activities. Turkish Journal of Computer and Mathematics Education, 1(2), 133-147.

Arslan, S., \& Ozpinar, I. (2008). Öğretmen Nitelikleri: İlköğretim Programlarının Beklentileri ve Eğitim Fakültelerinin Kazandirdıkları. "Teacher Qualifications: Gains and Education Department of Primary Education Curriculum Expectations”. Necatibey Ĕ̈itim Fakültesi Elektronik Fen ve Matematik Eğitimi Dergisi, 2, 38-63.

Aslan, G. (2007). Ankara Üniversitesi Eğitim Bilimleri Enstitüsüne kayıtlı doktora öğrencilerinin lisansüstü öğretime ilişkin sorunları. "Graduate education related problems of registered doctoral students at Ankara University Institute of Education Sciences" Milli Eğitim Dergisi, 174, 250-269.

Baird, L. L. (1975). Comparative Prediction of First Year Graduate and Professional School Grades in Six Fields. Educational and Psychological Measurement, 941-946. http://dx.doi.org/10.1177/001316447503500423

Bakioglu, A., \& Gürdal, A. (2001). Lisansüstü tezlerde danışman ve öğrencilerin rol algıları: yönetim için göstergeler, "In graduate thesis advisor and role perception of students: Indicators for management, Hacettepe University Journal of Education, 21, 9-18.

Bumen, N. T. (2006). Doktora eğitimi yapan öğrencilere yönelik yürütülen "Öğretimde Planlama ve Değerlendirme” ile "Gelişim ve Öğrenme" derslerinin değerlendirilmesi, "Doctoral education for students who carried out the "Planning and Evaluation in Teaching" and "Learning and Development" course of evaluation, Journal of Theory and Practice in Education, 6, 9-43.

Day, C. (1999). Developing teachers: the challenges of lifelong learning. London: Falmer Press.

Demir, C. (2007). Lisansüstü eğitim Alan öğrencilerin eğitim-öğretim sürecinden beklentileri ve beklentilerinin gerçekleşme düzeyi. "Graduate education achievement levels of students' expectations and the expectations of the educational process “(Paper presented at the 3th Lisansüstü Eğitim Sempozyumu, Eskişehir).

Dindar, H., \& Yangın, S. (2007). İlköğretim Fen ve Teknoloji Dersi Öğretim Programına geçiş sürecinde öğretmenlerin bakış açılarının değerlendirilmesi, "Evaluation of Primary Curriculum Science and Technology teachers' perspectives on the transition process", Kastamonu University Education Journal, 15, 185-198.

Drecko, R. F., \& Wounderberg, H. W. (1977). MBA Admission Criteria and Academic Success. Decision Sciences, 8, 765-769. http://dx.doi.org/10.1111/j.1540-5915.1977.tb01120.x

Duban, N., \& Kucukyılmaz, A. (2008). Sınıf Öğretmeni Adaylarının alternatif ölçmedeğerlendirme yöntem ve tekniklerinin uygulama okullarında kullanımına ilişkin görüşleri, "Class teacher assessment and evaluation methods and techniques of alternative views on the use of candidate applications in schools", Elementary Education Online, 7(3), 769-784.

Ekinci, C. E. (2009).Türkiyede yükseköğretimde öğrenci harcama ve maliyetleri, "Students in higher education spending and costs in Turkey", Eğitim Ve Bilim, 34(154), 119-133.

Ekinci, C. E. (2011). Bazı sosyo ekonomik etkenlerin Türkiyede yükseköğretime katılım üzerindeki etkileri. "Some socio-economic factors impact on participation in higher education in Turkey", Ĕ̈itim ve Bilim, 36(160), 281-297

Fullan, M. (1998). The Meaning Of Educational Change: A Quarter Of A Century Of Learning, International Handbook of Educational Change Kluwer International Handbooks of Education, 5, 214-228.

Gayle, J. B., \& Jones, T. H. (1973). Admission Standards for Graduate Study in Management. Decision Sciences, 421-425. http://dx.doi.org/10.1111/j.1540-5915.1973.tb00566.x

Gok, T., \& Sılay, I. (2008). Fizik eğitiminde işbirlikli öğrenme gruplarında problem çözme stratejileri öğretiminin problem çözmeye yönelik tutum üzerindeki etkileri, Journal of Theory and Practice in Education, 4, $253-266$.

Goktaş, Y., Yildirim, Z., \& Yildirim, S. (2008). Bilişim Teknolojilerinin ilköğretim ve ortaöğretim ile bütünleştirilmesindeki anahtarlar: öğretmenlerin algıları ve kullanımları, Hacettepe University Journal of Education, 34, 127-139.

Guven, I., \& Tunç, B. (2007). Lisansüstü öğretim öğrencilerinin akademik sorunları (Ankara Üniversitesi Eğitim 
Bilimleri Enstitüsü Örneği), "Academic problems of students graduate faculty (Ankara University Institute of Educational Sciences Example)”, Milli Eğitim Dergisi, 173, 157-171.

Hagan, M. T., Demuth, H. B., \& Beale, M. H. (1996). Neural network design. Boston: PWS Publishing. Herrera, O. L. (2006). Investigation of the role of pre- and post-admission variables in undergraduate institutional persistence, using a Markov student flow model. PhD Dissertation, North Carolina State University, USA.

Hattie, J. A. C. (2002). Classroom Composition and Peer Effects, International Journal of Educational Research, 37(5), 449-481. http://dx.doi.org/10.1016/S0883-0355(03)00015-6

Haykin, S. (1999). Neural networks: A comprehensive foundation (2nd ed.). New York: Prentice-Hall.

Ibrahim, Z., \& Rusli, D. (2007). Predicting Students' Academic Performance: Comparing Artificial Neural Network, Decision Tree and Linear Regression. 21st Annual SAS Malaysia Forum, 5th September 2007

Jun, J. (2005). Understanding dropout of adult learners in e-learning. PhD Dissertation, The University of Georgia, USA.

Karamouzis, S. T., \& Vrettos, A. (2008). An artificial Neural Network for Predicting Student Graduation Outcomes, Proceedings of the World Congress on Engineering and Computer Science WCECS2008, San Francisco, USA

Kardana, A. A., Sadeghia, H., Ghidaryb, S. S., \& Sania, M. R. F. (2013). Prediction of Student Course Selection in Online Higher Education İnstitutes Using Neural Network, Computers \& Education, 65, 1-11. http://dx.doi.org/10.1016/j.compedu.2013.01.015

Kıncal, R., Ergül, R., \& Timur, S. (2007). Fen Bilgisi öğretiminde işbirlikli öğrenme yönteminin öğrenci başarısına etkisi, Hacettepe University Journal of Education, 32,156-163.

Kuzu, A., \& Becit, G. (2007). Öğretmenlerin lisansüstü eğitimde karşılaştıkları sorunlar ve çözüm önerileri. (Paper presented at the 3th Lisansüstü Eğitim Sempozyumu, Eskişehir).

Lee, Y. (2010). Neural network based approach for predicting Learning effect in design students. The International Journal of Organizational Innovation, 2(3).

Lykourentzou, L., Giannoukos, L., Mpardis, G., Nikolopoulos, V., \& Loumos, V. (2009). Early and dynamic student achievement prediction in e-learning courses using neural networks. Journal of the American Society for Information Science and Technology, 60(2), 372-380. http://dx.doi.org/10.1002/asi.20970

Lykourentzou, L., Giannoukos, L., Nikolopoulos, V., Mpardis, G., \& Loumos, V. (2009). Dropout prediction in e-learning courses through the combination of machine learning techniques. Computers \& Education, 53(3), 950965. http://dx.doi.org/10.1016/j.compedu.2009.05.010

Marquardt, D. W. (1963). An algorithm for least-squares estimation of non-linear parameters. Journal of the Society for Industrial and Applied Mathematics, 11(2), 431-441. http://dx.doi.org/10.1137/0111030

McGhan, B. (2002). A Fundamental Education Reform: Teacher-Led Schools, Phi Delta Kappa International, 83(7), 538-540. http://www.jstor.org/stable/20440190

Naik, B., \& Ragothaman, S. (1997) Using Neural Network to Predict MBA Student Success. Journal of Education for Business, 69-74.

Orbeyi, S., \& Guven, B. (2008). Yeni İlköğretim Matematik Dersi Öğretim Programı'nın değerlendirme öğesine ilişkin öğretmen görüşleri, "New Mathematics Teacher Education Program of opinion regarding the evaluation items", Journal of Theory and Practice in Education, 4(1), 133-147.

Paolillo, J. G. P. (1982). The Predictive Validity of Selected Admission Variables Relative to GPA in a Master of Business Administration Program. Educational and Psychological Measurement, 1163-1167. http://dx.doi.org/10.1177/001316448204200423

Rumelhart, D. E., Hinton, G. E., \& Williams, R. J. (1988). Learning representations by back-propagating errors. Cognitive modeling, 5(3), 1. https://books.google.com.tr/books

Saltelli, A., Tarantola, S., Campolongo, F., \& Ratto, M. (2004). Sensitivity Analysis in Practice. A guide to Assessing Scientific Models, John Wiley\& Sons Publishers. https://books.google.com.tr/books

Schwan, E. S. (1988). MBA Admissions Criteria: An Empirical Investigation and Validation Study. Journal of Education for Business, 158-162. http://dx.doi.org/10.1080/08832323.1988.10117300

Tural, K. (2004). Küreselleşme ve Üniversiteler. "Globalization and Universities”, Ankara kök yayıncıllk

Umay, A. (2004). İlköğretim Matematik Öğretmenleri ve Öğretmen Adaylarının öğretimde Bilişim Teknolojilerinin 
kullanımına ilişkin görüşleri, "Elementary Teacher of Teachers of Mathematics and the teaching of the candidates' opinions on the use of Information" Technology Hacettepe University Journal of Education, 26, 176-181. https://scholar.google.com.tr/scholar?q=Umay,+A.+(2004)

Usluel, Y. K., Mumcu, F. K., \& Demiraslan, Y., (2007). Öğrenme-öğretme sürecinde Bilgi ve İletişim Teknolojileri: öğretmenlerin entegrasyon süreci ve engelleriyle ilgili görüşleri, "Information and Communication Technologies in the teaching-learning process: teachers' views on the integration process and obstacle", Hacettepe University Journal of Education, 32, 164-178. http://eku.comu.edu.tr/article/view/5000108976

Wheatley, M. (2002). Turning to one another: Simple conversations to restore hope to the future, The Journal for Quality and Participation, 25. http://asq.org/pub/jqp/past/2002/summer/

\section{$(\mathrm{Cc}) \mathrm{EY}$}

This work is licensed under a Creative Commons Attribution 3.0 License. 